a very late date for Weiss' redactor and a rather early date for the currency and influence of the fourth Gospel.

I need not follow this further. But the general suggestion of Johannine influence upon the text of Mark, and also, in the cases mentioned, of Luke, opens up a problem which has, and had for Weiss, a peculiar interest. I shall have to return later to Weiss' handling of certain Johannine questions. At this point I only wish to suggest that in the case of Luke, at least, it is wise to be very chary of admitting isolated and sporadic contamination from John: and that because such admissions may prejudice and hamper our consideration of a delicate and, as yet, unsettled question - the question, namely, of the general relation of the Lukan to the Johannine tradition. That relation might prove, and would, I think, on close investigation, prove to be a rather close one: or, I might say, if we could confront Canon Streeter's Proto-Luke with an Ur-Johannes, it would be found that they were:fairly near of kin; and the logical order of procedure required by the facts would place first a general investigation of the relationship which I have alleged, and after this the consideration of particular passages such as those which may or may not form part of the original Lukan text of chapter xxiv.

H. N. BATE.

(To be concluded.)

\title{
THE RUSSIAN CHURCH UNDER THE BOLSHEVIKS
}

\author{
Sacred to the Memory of my Martyred Brother Alexander, \\ Shot BY THE Bolsheviks IN THE TOWN OF URALsK ON THE NIGHT OF \\ June 25/12 to 26/13, 1919, and whose Body was Thrown into the \\ Ural River aNd Never Recovered. \\ Unto him be eternal memory. \\ "And the light shineth in darkness."-St. John i. 5.
}

INFINITELY calamitous is the fate of Russia. It appears a moral disaster to all who are not yet completely overpowered by purely egoistical pursuits and have still retained a certain amount of human sensitiveness. If the shock of a sudden great joy may sometimes occasion death, no imagination can stand the horrors of socialistic fury let loose. Many are acquainted with and realize this fact, but we must warn them that this overwhelming external aspect is infinitely below the terrible reality. Only a personal experience of this inferno may give an adequate idea of its actual frightfulness. Material losses, in spite of their "astronomic" proportions, may, nevertheless, be recovered. In that respect Russia is still the "country of 
illimitable possibilities," if only for the reason that her natural wealth is almost untouched.

Until the Revolution of the spring of 1917 the Russian Orthodox Church was united to the State, and was called upon to share in its destinies. It was but natural that the convulsions of the State left her defenceless and helpless against attacks, doomed to disintegration, owing to the absence of props within herself which she had never possessed before, and which it was now too late to put up. Her entire dependence on the State was so profoundly rooted that with the disappearance of governmental guardianship her own downfall seemed inevitable. This was apparently so obvious that even the most loyal admirers felt their trust in "Holy Russia" somewhat shaken, in spite of personal grief at the loss. Mr. Athelstan Riley, an intimate friend of the best foreign expert on Russian Orthodoxy and of its mystically fervent adept Mr. Birkbeck, who died suddenly on June 9, 1916, in his fiftyseventh year, nevertheless considered that the latter was felix opportunitate mortis, as it was to be apprehended that the Russian aspect of religion and the Church, downtrodden by the Revolution, would have broken his heart. He (i.e., Mr. Riley) holds it as a symptom worthy of note that the name of God in recent official documents is mentioned only in the dignified farewell manifesto of the Tzar Nicholas II., and as early as June, 1917, asks:

"Are Russia's splendid shrines to be destroyed and her Church, which made her great, humbled to the dust? Are all the glory and solemnities to pass away as a dream? Domine Deus tu nosti. The author thinks that the weakness of the Church of Russia in the face of these tremendous political changes lies in her strong Byzantine traditions, emanating from a past when the Eastern Church and Empire were closely linked together through the personality of the Emperor. The tendency in later times, notably in the reconstruction of national institutions by Peter the Great, has been to accentuate these traditions and to destroy still further the independence of the Church. Thus, the modus vivendi of a "Free Church in a Free State,' advanced by liberal French Catholics after the French Revolution had put an end to the old ideal of the relation between Church and State, would mean for the Russian Church a complete reversal of her historical growth. Can she adapt herself to altered circumstance-i.e., existence within a neutral or even hostile State? What will be her fate when exposed to the competition of the rival Churches and sects? Nothing just like the present crisis has ever happened to the Eastern Church before; in many ways the fall of Constantinople 
and enslavement of the Greek Church by the infidel was an easier shock to withstand. This is the weakness of the Russian Church; her strength lies in the devotion of her people, especially of her peasantry. If her children are not led away by the glamour of material and earthly things; if they still preserve their simple and touching devotion to our Lord, so conspicuous, for instance, in their pilgrimages to the earthly Jerusalem; if they still trust in the protection of His Most Holy Mother, and the fellowship of Jerusalem which is above, then the Church of Russia may launch out boldly into the deep, knowing that from all temptations and troubles allowed by the good God $\mathrm{He}$ has provided a way of escape that we may be able to bear them."*

Such an alternative tremulously apprehended by a sympathizing soul was at the beginning of 1919 boldly taken for granted by Roman Catholics, who, after the Revolution, had in relation to Russian Orthodoxy assumed the attitude of the roaring lion (1 Pet. v. 8). Even the most well-disposed French Roman Catholics wrote of the Russian Church: "Suddenly the political system on which it rested collapsed, and the Church found herself free and dispossessed. It has lost many of its faithfulindeed, so many that it might be asked if 'Holy Russia' has not ceased to exist. She has tried, in the midst of widespread indifference, to organize herself, but her best concerted attempts, such as the General Council of Moscow in 1917, have only revealed her powerlessness. After close guardianship for long centuries, habits of independence and liberty cannot be learned in a day." $\dagger$

What is the actual state of the Russian Church after more than four years of Bolshevist "wrestling against God "? How far and which of their expectations and aspirations have been fulfilled?

After the overwhelming Revolution the destinies of the contemporary Russian Church have been placed in the hands of the people, and that in conformity with the belief of the Orthodox East that " the guardianship of piety is committed to the body of the Church-i.e., to the people itself." $\ddagger$ And lo! herein awaited disappointment so profound that many persons, particularly Liberals of the "Populist" party, cannot even now recover their senses. The patented advocatus diaboli

* Athelstan Riley, Birkbeck and the Russian Church. London, 1917. Pp. 359, 361-63.

† Professor S. Calvet, French Catholics and the Russian Church. See The Constructive Quarterly vii. 1 (March, 1919), p. 41.

$\ddagger$ Thus says the "Encyclical of the One, Holy, Ecumenical (Catholic) Apostolic Church to all Orthodox Christians," edited in May, 1848, under the Patriarch Anthimus VI. of Constantinople (in reply to the Encyclical of Pope Pius IX., written January 6, 1848, and containing an appeal to Eastern Christians) and accepted in Russia. 
RUSSIAN CHURCH UNDER THE BOLSHEVIKS 227

of Bolshevism, the writer Maxim Gorky (A. M. Pieshkov), himself of obscure workman origin, is now vociferating furiously against the "blind and unbridled peasantry, the primitive and low-browed beast imbued with instincts of possession," who is "keeping a blood-stained feast of commemoration, drowning our (Russian) cities in blood, destroying wholesale the brain of the nation."* Another literary pigmy of the "Populist" type, a certain V. Mouighel, prates incoherently about the "simple-minded Russian," who, having only now recovered himself, " has become aware that he has overdone it, and the results are not quite up to his expectations. He, like a savage, has rudely thrown off his yoke and shocked the 'cultured' world, so alien to his own special form of culture; and 'in the fight' has done that the memory of which makes him now scratch his head." $†$ The pseudo-" Slovophils" from among patriotic reactionaries, who erstwhile were the loudest to sing the praises of the great Orthodox Russian people, and threatened to "do away" with the "rotten West," are now the first to hurl their invectives and, accusing Dostoievsky, call their former idol, not the "bearer of God," but a "bearer of the devil." And numerous profoundly sad events cannot be denied. It seemed as if the billows of some wicked epidemic of insanity had swept over the people, drowning everything in their muddy, seething froth. . . . Their flying spray has tainted the Church and left its dark traces to this day. But this was but an outburst of the epidemic, and has long since lost its acuteness, after demonstrating that the innermost being of the Russian does not correspond to his outward appearance, which absorbs his generosity and distorts his innate nobility into a monstrosity.

In this case the anti-religious socialistic insanity was confined to the more or less narrow circles of the town mob, factory hands, and "green" village youth intoxicated by Communist temptations. The people itself remained almost entirely alien to such abnormal excesses, only did not offer any organized opposition, and did not prevent them, thereby tolerating them. Instead of active resistance, the people preferred to suffer for their religion, thus justifying the words of the poet Nekrassov that they were " a people whose patience amazed the world." The Russian people was always accustomed to live in a " commune" and act "in common," but on Christian principles, and therefore never sympathized with atheist experiments, however tempting their guise. The mass of the people eyed the development of the newly implanted Communism with curiosity as long as the latter seemed compatible with, and issuing

* See the Communist Helsingfors paper Put, No. 176, September 20, 1921. $\dagger$ See same, No. 246, December 11, 1921. 
from, Christianity. A certain Liberal, well known in the "official spheres" of Bolshevism, and a complete internationalist, testified to us that the real peasant Russia would only accept Lenin if that brigand hero would appear before her bearing an ikon of Christ in his hands and preceded by a priest with a Crucifix. As these rude, intolerant, and odious Communists never were, nor will be, capable of such an act, Communism has disappeared from the minds of the people even as an object for comparative observation, and has at once become an accursed object of loathing and horror.

The last census of the Communist party has shown that it has lost an enormous number of peasants, also many "intellectuals" and workmen, and in a very great number of cases they left the party for religious motives. This is all the more significant because withdrawal from the Communist party is always followed by specially malicious reprisals, whereas loyalty to Communism is rewarded by great material benefits and a multitude of social and administrative privileges.

Besides these material allurements there were constant spiritual temptations. We do not speak of the direct SocialistBolshevist propaganda with which everyone was literally overwhelmed-but even that was disgustingly blatant and earsplitting, and aroused the gradually increasing opposition in the souls of the people. It was supported by the more subtle influence of the fallen or venal "intellectuals," who tried to seduce the conscience of the people by various religiously decadent combinations. A certain Andrei Bely (White), who adopted that colour as an absolute contrast to his own blackness, and who, with his father, the well-known Moscow mathematician N. Bugayev, founded a regular idealistic schoolthis Lombroso type tried, by means of poisonous rigmaroles, to prove that the Golgotha of Christ was crowned and realized in Jewish-Russian Bolshevism. . . . For this purpose it was necessary to undermine faith in the Church. ... The Bolsheviks launched a veritable attack on the latter, so as to stun the people by a decisive atheistical onslaught. A coarsely blasphemous play, The Celestial Mechanism, was composed, in which all the force of socialistic beastliness was used to mock at all religious beliefs, while the Deity and the saints were caricatured as contemptible frauds and adventurers. The very best " artistes" were called upon to act this play, and put forth all their contemptible and venal skill, being paid at increased rates, and receiving extra rations as a reward. The Communist bards were wild with delight in describing the thrilling animation of the actors and the warm enthusiasm of the audience, who, they declared, irresistibly showed their blas- 
phemously atheistic ardour. Whether this was so, even once only, we do not know, nor can we deny it; but in any case, after a short run of a few days, the play was withdrawn, and all reference to it ceased absolutely. The great significance of this lies in the fact that this took place in Petrograd, the capital, in the centre of factory workers, at that time carried away by Communism. If here the attempt failed absolutely, there was no chance of its succeeding in the provinces, where these vile compositions did not penetrate, as it was too obvious that the people were absolutely impermeable to atheistic propaganda, either direct or indirect, positive or negative, either in word or deed, either by sacrilege or by blasphemy. . . .

\section{II}

I give only a few of the more striking examples of the various and many-sided spiritual temptations which tended to shake the stability of the Russian character and dominate it, to bewilder the sober minds of the nation, and thus imperceptibly poison them with the blasphemy of the vilest religious falsifications. For this purpose special proletarian "catechisms" and soldiers' "manuals" were compiled, in which the commonly used Christian Church prayers were sacrilegiously parodied in the socialistic-Bolshevist manner, serving as a convenient means of introducing the atheistic Communist poison.

The Russian people bore everything in their wide comprehensiveness, which does not exclude the negative point of view, in so far as it humanum est.

In this the Russian people in contrario has shown its " national universality," and has confirmed the prophetic view expressed by the great literary seer, F. M. Dostoievsky, who in 1882, in his speech at the opening of the monument to the poet Pushkin in Moscow, said: "What is the strength of the Russian national spirit, if not a tendency, in its final aims, towards universality and 'all humanity'? ... . The Russian is destined to be All-European and universal. To become a real Russian, to become a complete Russian, may mean becoming the brother of all mankind, becoming an 'all-man,' so to speak. . . . Of all nations, the heart of the Russian is, perhaps, most fitted for universal brotherhood."

This sacred peculiarity of the Russian people is too perceptible and too indisputable to every Russian exile, who has had bitter experience of the full force of European universality and Western humanity. On the contrary, in the Russian, who knows no limits to the direct expression of humanity whenever an opportunity for such expression presents itself, we are always conscious of a warmth of natural emanation of 
all-human sympathy and of a whole-hearted willingness to help everyone, following the example of our Heavenly Father, " who maketh His sun to rise on the evil and the good, and sendeth rain on the just and the unjust." (Matt. v. 45). As the "people's" poet Nekrassov has truly said,

"Gold, gold, Is the heart of the people."

This inborn Russian tendency to universal goodwill has been misused for the material anti-Christian purposes of Communistic Bolshevism, which blinded and at first attracted adherents by its specious internationality, which seemed to be the best readymade form of universal brotherhood. This latter, however, can be realized by Russians only on the basis of nationality, and therefore only by means of religious Christian factors which are above nationality, which penetrate and rise to the limits of reality; otherwise it is a mere deception and satanic treachery.

It means that Russians tested Communism by Christianity, and found confirmation for it both in its likeness and its contradictions to the latter.

Practically, only the contradictions were found to exist. The popular power of the "People's Commissars" trampled the people's religion in the mud and suppressed all its pious requirements. In August, 1920, the workmen of several Petrograd works wished to hold a thanksgiving service on the feast of the Transfiguration, but the Communist usurpers contemptuously refused permission and billed the whole town with a sacrilegious " manifesto." At the end of 1921 several Moscow tobacco manufacturers formally and publicly passed a resolution that they would take a holiday for the purpose of celebrating the feast of the Birth of the Virgin Mary in church, and were heavily fined for it. When, on the grounds of its being a legalized day of rest and on the basis of the established number of working hours, the Moscow carters declined to cart wood fuel on a Sunday, they were discharged by the authorities as strikers. ....

The people took notice of all this, and, convinced that Communism was simply exploitation and oppression, "departed from it to do good" (Ps. xxxiv. 15), and became more firmly rooted in their Orthodox faith. They suffered for this faith, and kept to it throughout all the Bolshevist persecution, preserving it as their Holy of Holies, and showed themselves to the whole world as the "God-bearers." They were seduced from the Church by insidious accusations of its having become a traitor to the ideals of the people for the sake of political subserviency; but the people were clever enough to see through 
this deception, and returned to the bosom of the Church with submission, self-denial, and self-sacrifice. Now the Church is their only stay, and their last hope of any life. In it they find oblivion, comfort, and regeneration. People of all conditions fill the Orthodox churches, where one may meet workmen. Red Army men, and even Communists-sometimes responsible commissars. . . . This takes place in the capitals, in full view of the Bolshevist persecutors, in spite of all the restrictions as to time and numberless prohibitions and threats.

All the more undoubted is the unusual religious revival in the villages. The peasantry have become the only source of revenue and profitable victims of mad Bolshevist prodigality, and have lost their all, being obliged to hide their last remaining scraps from the rapacity of the Communists. In spite of all this, the peasants are very responsive to all religious demands, keeping their churches in good order and adequately providing for their clergy. A foreigner, strolling about ruined Petrograd, loudly expressed his astonishment that only the churches were being repaired, while many houses were collapsing and burying passers-by in their ruins. The clergy are fed so well that the Bolsheviks propose to introduce fixed rations for the clergy, and to forbid "free-will offerings." As regards religion, the Russian people have successfully passed their examination of martyrdom, and have not abandoned Orthodoxy either for atheism, foreign religions, or sectarianism, and have justified the fair fame of "Holy Russia."

Of course, such a favourable result of the demoniacal antiChristian experiment could not have been attained without the clergy, to whom the greater part of the honour is due. The higher clergy, especially the Patriarch, are worthy of special mention. Here it is sufficient to say that they were, and are, worthy of their highly responsible and, at present, dangerous position. The apostates are very few, being principally chance elements who had been appointed owing to the slackness and favouritism of the secular authorities who had set aside or evaded ecclesiastical control. Information is still coming to hand that Russian bishops are still shedding their blood rather than forsake their trust, and are still leaders of their Christian flock. The higher clergy have shed every vestige of administrative aloofness and bureaucratic seclusion, and have become really and truly shepherds of the people. At present there are over 200 bishops in Russia-a number never attained at the most flourishing period of Tzarism, and most astonishing in view of the enormous reduction of the territory under the jurisdiction of the Patriarchate. This alone shows the national popularity of the Russian episcopate, which has now reached the provincial strata, and has 
penetrated to the villages and hamlets, becoming the closest guide of the life of the people.

The rank and file of the Russian clergy are, proportionately, not a whit behind their superiors, while, taking all the circumstances into consideration, they may stand even higher. They perished without a murmur and without record in enormous numbers. According to certain data, the number of priests killed by the Bolsheviks reached 1,215; * but we have reason to think that the actual number was far greater, if all the ranks of the clergy are taken into account. Moreover, the number of apostates is very small, most of them being of the lower clergy - i.e., readers, clerks, and partly deacons, while hardly a priest is mentioned. Like true "soldiers of Christ," all remain at their sacred posts, which are, at present, especially conducive to salvation, and attract all sensitive and noble hearts by the opportunity for self-sacrifice. Therefore we now see in Russia what was very rare in former times - the highest Tzarist officials are taking Holy Orders as simple country priests, highly educated young men of noble birth leave the capital to become parish priests in far-away provinces, frequently acting as prison chaplains; eminent secular professors of their own free will enter Holy Orders, some of them even managing very successfully to combine service in the clinical hospital with that in the pulpit (e.g., in Tashkend). The clergy are constantly holding services, always with due solemnity. A great number of churches have good - even excellent - choirs, though congregational singing is widely spread. The Russian priest, historically and invariably near to the Russian people, has now become the authoritative instructor of the people in all " questions of life." Formerly sermons were somewhat of a rarity: now no service is complete without one, and even outside the church the most varied addresses on religious subjects are now given, attracting large audiences. Formerly the sermons were often very " bookish," and in towns often led to a perceptible exodus of the congregation; at the present time the people crowd round the pulpit, $\uparrow$ listening attentively, and there and then expressing their impressions, feelings, and desires.

Of course, under the new order there is no disciplined smoothness, and sometimes the ardour of neophytes, knowing no traditions or school, results in exalted originality and ecstatic impulsiveness, but gradually the stream is returning to its ordinary banks, and is filling those who are thirsting for the truth of God.

\footnotetext{
* See weekly review of the Supreme Monarchical Council in Berlin of November 28, 1921, No. 18, p. 3, in the article "The Soviet Golgotha."

$\dagger$ There are no pews in the Russian Church.
} 


\section{RUSSIAN CHURCH UNDER THE BOLSHEVIKS 233}

The people keep to the church and even take part in allnight services, which are now usually very well attended, and the clergy serve God for them and with them "from the morning watch until night" (Ps. xxxix. 5), and are a "light which the darkness comprehendeth not " (John i. 5).

Their close union is now confirmed by common martyrdom. Death is hovering all over Russia, and everyone is walking in its shadow. The shepherds have taught their flock to sacrifice themselves like Christians, and now all know how to offer their lives as a sacrifice to God. Bolshevist Soviet Russia is one enormous Nero's Colosseum. In this ready-made arena, among the infuriated, snarling, brutal cannibals, one can only pray and die, like all the Orthodox who perished at the hands of the Bolshevist executioners-fearlessly, heroically, grandly, and like true Christians.* I shall give a few examples, characteristic of the various categories of Churchmen.

In an ancient and wholly ecclesiastical corner of the Novgorod province a gang of Communists attacked the local monasteries and convents and dispersed the monks and nuns, arresting the more prominent members. Many were very old, among them being the aged bishop and a decrepit abbess. All were driven in a crowd through the frost into a field, the weak and stragglers being made to advance by blows of riflebutts. Bishop Varsonofi blessed and sped everyone, inspiring them with courage, so that all manfully stood in a row facing the muzzles of the rifles while the gallant bishop, who had formerly exposed the impiety of the Bolsheviks, knelt down and lifted his hands in prayer for all to the merciful God. Three volleys were fired, but the bishop remained immovable among the fallen and groaning - with enlightened eyes turned to the heavens to plead before the Father for sinful mankind. Then he said that he had finished and was ready to appear before God's Judgment Seat; but now the stifled conscience of the Red Army men was awakened by mystic terror, and they refused to shoot, and the bishop had to be killed by the devilish " commissar" himself, who for a long time would not allow the body of the bishop to be buried, but let it lie to be mocked at. Is this not a real martyr?

The late Tzar's chaplain, the Archpriest Alexander Petrovich Vassiliev, was a Smolensk peasant by birth. He was the pupil of the well-known educationist and humanist, Professor S. A. Rachnisky, and had never taken part in politics. He was arrested simply because of his nearness to the family of the Tzar, and was imprisoned in one cell with his son, a youth.

* According to the weekly review of the Supreme Monarchist Council (No. 18, 1921), Bolsheviks killed $1,766,110$ persons.

v. 28 
Here they languished for a long time (till the end of 1918), calculating when their turn to die would come. It is difficult even to imagine this slow torture. Finally the father was taken out to be shot in the bitter frost, in nothing but his underlinen. The worthy servant of God went to his death singing Psalm xxv.: "Plead my cause, O Lord, with them that strive with me; fight against them that fight against us," and, what was touching, prayed for his executioners, telling them that as a man and a priest he forgave them for their enforced execution of him. . . . Such lofty Christian spiritual courage is truly miraculous, just because it has become a source of courage to the faithful transmitted through the very mouths of his murderers.

The well-known Monarchist, Professor Boris Vladimirovich Nikolsky, was enticed from Voronezh by the Petrograd Communists, by being invited to read popular lectures at his own courses, and was soon condemned to death, together with a numerous party of other victims. He begged for and obtained the sad privilege of dying last, in order to bless and administer religious consolation to his unfortunate comrades, who did, indeed, give up their lives with heroic calmness. Through one of the Red Army men who took part in the evil deed, the Professor sent his blessing and prayer to his only daughter. The Bolsheviks took away his body to feed the wild beasts at the Petrograd Zoological Gardens, which was under the superintendence of the "artiste" M. F. Andreyeva, wife of Maxim Gorky, the Bolshevist apologist.* Does not this remind one of Nero's times, while exceeding them in satanic refinement?

The heathens of ancient times were astonished and awed by Christians dying, and thereby conquering by death itself. The Russian martyrs of the Bolsheviks are worthy of their early Christian prototypes, and, by God's grace, will yield the same blessed fruits.

At some " spiritual " Orthodox feast, a clergyman of another creed publicly expressed his opinion that no Church stood higher than the Russian, as no other had so many martyrs, and "the blood of martyrs is the seed of the Church," which spread Christianity and regenerated the ancient world. We believe that now, likewise, the Russian martyrs in communion with the departed and the Church Militant will regenerate "Holy Russia" by Christian means, and save the world from satanic anarchy for the Kingdom of God.

Professor Nicholas Glubokovsky, D.D.

Sunday, 1, 1/14, 1922.

IN ExiLE AT Kärstilü,

NeAR Wiborg, Finland.

* See the Helsingfors Novaya Russkaya Zizn (New Russian Life), No. 22\%, November 12, 1920. 